\title{
Management of Social Risks and their Impact on the Spheres of Human Life in the Conditions of Sustainable Development of Ukraine
}

\author{
Zarządzanie zagrożeniami społecznymi i ich wpływ na \\ ludzkie życia w warunkach zrównoważonego rozwoju \\ Ukrainy
}

\section{Halyna Zelinska*1, Uliana Andrusiv*2, Olga Galtsova**3, Mykyta Dmytrechenko**4}

*Ivano-Frankivsk National Technical University Of Oil And Gas, 15 Karpatska str., 76018, Ivano-Frankivsk, Ukraine

${ }^{1}$ Department of Applied Economics, ORCID: 0000-0003-2175-4883

${ }^{2}$ Department of Theory of Economics and Management,

E-mail (Corresponding Author): andrusivu@ukr.net, ORCID: 0000-0003-1793-0936

**Classical Private University, Department of National Economy, Marketing and

International Economic Relations,70-b Zhukovsky str., 69002, Zaporizhzhia, Ukraine

${ }^{3}$ ORCID: 0000-0003-0012-0371; ${ }^{4}$ ORCID: 0000-0002-3042-7916

\begin{abstract}
The aim of the article is to analyze risks in the social sphere and their impact on the development of society in Ukraine. Increasing the impact of risks in the sphere of demography, employment, remuneration, etc. in the context of sustainable development has been determined. The conducted research shows that the risks related to the labor sphere and the health of the population are the most aggressive and dangerous for the safety (as shown by the coronavirus pandemic) because protracted problems in the political, social and economic spheres are accompanied by job losses, economic decline, low wages for more than half of the working population. In view of the ambiguity and uneven economic development of the administrative territorial units of Ukraine it has been determined that education and knowledge can become a factor that can lead to the activation of innovative changes and reduce the negative impact of social threats. For this reason, the most important requirement for the sustainable development of Ukraine is the formulation of a social policy, based on an effective system of methods aimed at preventing risks and reducing probability of their occurrence.
\end{abstract}

Key words: risk, social sphere, labor force, human development, situation, labor market, education, measures, sustainable development, pandemic

\section{Streszczenie}

Celem artykułu jest analiza zagrożeń w sferze społecznej i ich wpływu na rozwój społeczeństwa na Ukrainie. Określono zwiększenie wpływu ryzyka w sferze demografii, zatrudnienia, wynagrodzeń itp. w kontekście zrównoważonego rozwoju. Z przeprowadzonych badań wynika, że zagrożenia związane ze sferą pracy i zdrowiem ludności są najbardziej agresywne i niebezpieczne dla bezpieczeństwa (o czym świadczy pandemia koronawirusa), ponieważ problemom w sferze politycznej, społecznej i gospodarczej towarzyszy utrata miejsc pracy, załamanie gospodarki i niskie płace dla ponad połowy ludności aktywnej zawodowo. Wobec niejednoznaczności i nierównomiernego rozwoju gospodarczego jednostek terytorialnych Ukrainy stwierdzono, że edukacja i wiedza to czynnik, który może prowadzić do aktywizacji innowacyjnych zmian i ograniczać negatywny wpływ zagrożeń społecznych. Dlatego najważniejszym warunkiem zrównoważonego rozwoju Ukrainy jest sformułowanie polityki społecznej, opartej na skutecznym systemie metod zapobiegania zagrożeniom i zmniejszania prawdopodobieństwa ich wystąpienia.

Słowa kluczowe: ryzyko, sfera społeczna, siła robocza, rozwój społeczny, sytuacja, rynek pracy, edukacja, środki, zrównoważony rozwój, pandemia 


\section{Introduction}

The civilization progress of Ukraine in the conditions of information society is impossible without the successful realization of strategic tasks in the political, economic, environmental and social spheres. The changes occurring in the economic sphere at the state, regional and macro levels have also affected social risks in the system of which complex processes are taking place: some of them are weakening in their action, others on the contrary are increasing. The impact of globalization on the economic development of Ukraine has created new conditions for the manifestation of social risks, increasing their degree of danger which is first of all manifested in the health of the population in connection with the spread of the pandemic coronavirus. Against the background of the increased aggression of the coronavirus pandemic, the economy of all countries of the world is suffering significant losses. The world made the disappointing conclusion that the virus infects people regardless of social and economic status. Poverty, inaccessibility to normal medical care, false news and provocations, emotional stress, social depression are becoming a threat to humanity as a whole. The economic downturn, external self-isolation of states and the introduction of internal quarantine regimes have become a reality. An alarming trend regarding risks in human development is warned by an analytical study by the United Nations Development Program (UNDP), which notes that many crises have occurred in the world over the past 30 years, including the global financial crisis of 2007-2009. Each of them dealt a severe blow to human development, but in general, from year to year, one could observe an increase in development indicators around the world. The COVID 19 pandemic could reverse this trend (United Nations Development Program). UNDP estimates that $60 \%$ of children are out of education due to school closures. Given this and the significant inequality in access to online learning, $86 \%$ of primary school-aged children now have virtually no education in countries with low human development, compared with only $20 \%$ in countries with very high human development indicators (ibid. ).

The United Nations Conference on Trade and Development (UNCTAD) predicts a 5-15\% reduction in global foreign direct investment (UN Conference on Trade and Development (UNCTAD). Today, more than ever, there is a need for risk management in various aspects of the social sphere (demographic, labor, health care, education, ecology, etc.), analysis of their specific features and formation of priority tasks of the state to ensure social stability in society development.

\section{Review of literature}

Risk problems, including social ones, are researched for a long time by different scientists both foreign and Ukrainian Thus, a number of publications have been devoted to the assessment of social risks, in particular by scientists (Shapovalovoi et al., 2016) conducted a study of the cause and effect transformation of communications in the natural, socio-cultural and anthropogenic areas of personal habitat and major social risks.

The result of the work was the prediction of the probability of occurrence of social risks and an assessment of their importance in the context of the formation of the general situation in the society of the country. Mozgovaya (2018) proposes to assess social risks not only by socio-demographic characteristics, but also by the level and quality of life of the population, its individual and worldview features. Shapovalova et al. (2018) analyzed the structure of threats and risks of the habitat, identified the most effective countermeasures at the state level. Consideration of social risks in the energy sector has become the subject of research by scientists (Karimi et al., 2016; Kneysler et al., 2020), they prove that the transition to a constant energy regime is not only about engineering but also about social and cultural issues. They justify the role of the public in overcoming social risks in the energy sector.

Le Coze (2018) explored the relationship between public safety and the global world. He proposes risks to be divided into socio-technological risks, systemic risks and existential risks. He claims that our vision of social security needs to be understood through an understanding of how these three types of risks are intertwined, how the global problem challenges the governance of society in general and the governance of the security of the state in particular. Motta (2015) describes the use of social risks in national public discourses. In conclusion, the author proved the recognition of the need to take into account various aspects of opportunities to prevent social risks, such as political, discursive and economic in terms of sustainable development. Authors (Falconi et al., 2020) investigated the social problem as a change women 's employment structure during the World War II era affected the risk of their disease and mortality. As a result of the analysis the authors concluded that an older group of women who joined the workforce before the outbreak of World War II found ambiguous differences in health In the younger group of women who joined the workforce during World War II, the trend revealed negative links between work during the late postpartum age and health, experiencing higher mortality risks. Hence, the authors state that women 's employment is influenced by politics, demographics, social forces and the environment in which they live.

Work and its role in shaping the social gradient in health by Clougherty (et al., 2010) proves the 
relevance of the risk-related problem in the social and labor sphere and in the fields of demography and health care. In fact, employment is a social gradient metric first used to study the relationship between the etiology of social class and chronic disease. The work carried out the study of 6 risks: the role of status in the hierarchical professional system; The role of psychosocial hazards of work; Consequences of physical and chemical hazards in the workplace; Evidence that labour organization matters as a contextual factor; Consequences for gradient of new forms of non-standard or unstable employment, such as contract work and shift work; And new evidence that women can react differently to adverse working conditions. These risks affect people's health differently. Zelviene, Kazlauskas, \& Maercker (2020) concluded in their work that work-related stresses and healthrelated stresses were significantly associated with impaired adaptation and that the type of stress is influenced by demographic characteristics.

Delaney (2019) considers the joint impact of labor market risks and selection to employment on the assessment of income from education received. It is proved that for women educational risks have particular importance when applying for work. They are significantly higher than men.

Delaney \& Devereux (2019) prove that the level of education directly affects the increase in the employee 's earnings. The results show that men who underwent changes before the law afterwards had less wage variability and less procyclical earnings. However, there is little evidence that education affects the variability of older people 's earnings. Schuring et al. (2019) have justified that in all European regions there are inequalities in education and it affects the health and earnings of workers.

It is substantiated that science and education are a reliable segment for the spread of innovation (Andrusiv et. al., 2017; Zelinska et. al., 2020; Popadynets et. al., 2020). Kinash et. al., (2019) it is said that the development of the infrastructure of the country contributes to the improvement of social infrastructure. Ievdokymov et. al. (2020) in their study proved that social security should be viewed through the lens of social capital, as it is a limited real or potential resource of social interaction.

Economic conditions with labour market instability and higher unemployment rates create a scenario where the risk of poverty and social exclusion can affect young people and push them away from socioeconomic participation in the life of the state, claim (Ruesga-Benito et al., 2018) in their research. Such social risks lead to an increase in unemployed persons in general and among young people.

So, the in-depth analysis of the scientific literature on the impact of social risks on different aspects of life in terms of sustainable development proves the relevance of the problem and points to its multidimensionality. However, the simple transfer of foreign experience of the impact of risks on society to the realities of the Ukrainian state is impossible due to a number of different factors, in particular the peculiarities of the mentality of the population, its cultural and ethnic customs.

Despite the multifaceted study by foreign and domestic scientists of the problem of the emergence of various kinds of risks and the influence of their individual components of the economic, political and environmental sides in the current conditions of sustainable development of Ukraine Ukraine remain poorly investigated. Therefore, the need for in-depth study of them in particular of social risks in both theoretical and applied aspects is actualized.

\section{Social risk methodology and the measurements that measure}

In the process of generalizing the theoretical foundations of knowledge of the nature of risks, it has been found out that this problem remains relevant in science due to its interdisciplinary nature. The extent to which the state consistently implements effective policies in the fields of economy, politics, ecology will depend on the social security of the state. With the spread of the coronavirus pandemic in the world, the mass return of migrants home to Ukraine, the shutdown of enterprises and organizations, the issue of the emergence and spread of social risks becomes particularly acute, and therefore the analysis of their impact on society today's requires in-depth methodological research and special response from the state.

\section{Social risk analysis in Ukraine}

In modern conditions, the intensity of risk manifestation is constantly increasing. Ukraine has become resilient, threatening trends in the demographic situation (high mortality and mass labour and intellectual migration abroad and today also the return of migrants home), a decline in living standards and instability in the social and labour sphere (which lead to deepening employment risks, rising unemployment rates) an increase in poverty and social insecurity of the population, which limits their access to medical care and quality nutrition. The continuing protracted problems in the political, social and economic spheres are accompanied by job losses, economic decline, low wages in the majority of the working population. All this increases negative sentiment in society and causes new social risks in terms of sustainable development.

In examining social risks, we emphasize that risks are defined as the dangers that appear within the social sphere and the potential for negative consequences for both the individual and society as a whole due to the occurrence of certain events. Such dangers include a decline in the number of workingage populations, an increase in labour migration, an 
increase in unemployment, a decrease in the income of the population and its standard of living.

Demographic factors are an important prerequisite for the social security of the State and the stability of the development of the labour market. Among the main indicators that characterize demographic factors and reflecting on structural transformations of the labour market, we note the birth and mortality rates of the population, natural and mechanical growth, migration coefficients of working age population, average life expectancy, etc.

Between 1991 and 2018 the population in Ukraine decreased from 52.1 million to 42.0 million namely for 10.1 million people. If in 1991 , according to the State Statistics Committee of Ukraine, there was a natural decrease in the population due to the excess of the number of deaths over the number of births by 39.1 thousand people then in 2018 - the indicator crossed the limit over 220 thousand people. The lowest fall in fertility was recorded in 2015 (11.6\%) (State Statistics Service of Ukraine, 2019). Despite the positive dynamics in the rate of fertility decline, Ukraine remains the leader in some types of diseases. According to the World Health Organization (WHO) in 2016. 392 thousand deaths occurred as a result of diseases of circulatory systems and for the reasons of malignant neoplasms 79 thousand people died in 2016 (13\% of all reported deaths). Menacing statistics of the road accidents (RA), suicide, complication after operations, diseases of tuberculosis and many other things. On average, more than 4,000 people are killed in road accidents annually. Among the main reasons for this WHO refers to speeding, drunk condition of drivers, telephone conversations while driving, etc (World Health Organization, 2015). According to WHO data for 2015, Ukraine ranked $23^{\text {rd }}$ place out of 172 countries in terms of suicide deaths (World Health Organization, 2015). The sad statistics of the demographic situation in Ukraine show not only the quantitative decline of the population in the state but also leads to reflection on its future. Confirmation of this fact is the superiority of Ukraine in mortality rate determined by the UN and the last place among the EU countries in the index of life expectancy of the population.

The nature of demographic processes in terms of sustainable development states creates an unfavourable environment for people 's lives, manifested in such risks as the risk of premature death; Risk of dying from tuberculosis, risk of falling below the poverty line after the birth of a child;Risk of breaking family ties as a result of migration; Risk of loss of social protection due to forced labour illegal migration, risk of failure to receive retirement pension as a result of lack of required insurance experience, risk of loss of breadwinner, etc.

Regarding to labour migration for the majority Ukrainian it acts as a specific type of permanent employment due to the inability to find decent work in the homeland. The inability to maintain family members or the desire to improve their material wellbeing have been motivated by the emigration of people of working age, both men and women. According to a sample survey of the households of the IOM Office in Ukraine, the majority of migrant workers are from Western regions. Thus, only from the regions of the Carpathian region (Lviv, Transcarpathian, Ivano-Frankivsk and Chernivts) about 700 thousand people annually go to temporary works abroad and in general this process covers from 5 to 7 million citizens of Ukraine (Report of the Survey of Innovation Activity in the Economy of Ukraine, 2019). Men aged 30-44 predominate among migrant workers. A significant proportion of migrant workers from Ukraine work abroad illegally. Since 1995 representatives of less skilled types of labour builders, drivers, locksmiths, waiters and housewives - have been involved in emigration, in addition to persons of skilled types of work. The main countries of employment for Ukrainians in recent years were Poland, the Russian Federation, the Czech Republic, Italy and Spain. These countries account for more than $80 \%$ of labour migration flows of Ukrainian residents (Malinovskaya, 2016). According to the State Border Service Poland is the most popular country for the work and life of Ukrainian. The most active departure process was observed in 2015-2017. Poland 's economy continued to grow and wages, according to the National Bank of Ukraine, for various types of activities exceeded Ukrainian by 4-6 times (in total in agriculture and construction). In addition, the country is nearby and it is easy for Ukrainians to adapt due to the close cultural field.

The outflow of personnel abroad is taking on a large scale, Ukrainian specialists fill niches mainly from low-paid jobs in the international labour market. The negative consequences of the risks of labour migration fully leave a mark in the social and domestic sphere (divorce from the family, wastefulness on the part of migrant children), lead to a decrease in professional level, discomfort related to integration into the new cultural and economic environment. In addition, potential risks of illegal employment abroad include possible discrimination and humiliation of human dignity, irregular working hours, threat of deportation, inability to obtain qualified medical care due to lack of health insurance, lack of guarantees with regards to getting earned money, dependence on criminal elements, which often causes a threat to health and life.

Particular attention needs to be paid to internal migration regarding displaced people as a result of Russian aggression in the east. The imperfection of the regulatory framework for such persons in Ukraine creates new social risks: risk of loss of housing, risk of poverty, risk of uncertainty in the future.

A generalized indicator of the level of development of individual states is the Human Development 
Index (HDI). By this indicator, Ukraine ranked 88th among 189 countries with a value of 0.751 in 2018 and by happiness index in $2019-123^{\text {rd }}$ place out of 156 countries in the world which indicates a lack of attention on the part of the State to human development in general (State Statistics Service of Ukraine, 2018).

In the near future, Ukraine is expecting a rapid depopulation, reduction and ageing of the population at a rapid pace. Therefore, the demographic forecast for Ukraine's sustainable development becomes disappointing.

According to the Institute of Demography the population will have decreased by 5.5 million people by 2050. At the same time, the number of people of working age (20-59 years ) will decrease by 6,6 million people, while the number of people aged 60 and over will increase by 2,6 million people, their share in the population (ageing level) will grow to $33 \%$. The ratio of age contingents of labour force (20-59 years) to retirement age (60 years or more) will decrease from the current 2.6 to 2 in the early 2030s and to 1.5 at the end of the projected period (Tkachenko, 2017). According to the forecast published in 2017, the population of Ukraine will have decreased to 38.5 million people by 2050 , to 36.0 million people by 2100 (Tkachenko, 2017).

The unfavourable situation in the sphere of demography in the conditions of sustainable development of Ukraine has become in fact a precondition for the risks that accompany the labour market. The demographic characteristics of the population thus serve as a basic element of assessing the prospects and opportunities of forming a supply in the labor market. According to the State Statistics Agency of Ukraine, the average monthly number of economically active population aged $15-70$ years in 2017 compared to 2016 . It decreased by $0.6 \%$ to and amounted to 17.9 million people, of which 17.2 million were of working age. Out of the indicated number of citizens aged 15-70 years, 16.2 million people or $90.5 \%$, were engaged in economic activity and the remaining 1.7 million people were unemployed. The level of economic activity of the population aged $15-70$ decreased from $62.2 \%$ in 2016 to $62.0 \%$ in 2017 . The number of employed population aged $15-70$ in 2017 decreased by $0.7 \%$ compared to 2016 and amounted to 16.2 million people, of whom 15.5 million are in the working-age. The highest employment rate of the working-age population was observed among people aged 35-49 years and the lowest in young people aged 15-24 and those aged 60-70 years (State Statistics Service of Ukraine, 2018). The unemployment situation has intensified. Unemployment rate at the age of 15-70 in 2017 in comparison with 2014 was $9.5 \%$ of the economically active population of the specified age, and $9.9 \%$ of the population of working-age. The corresponding indicator for the European Union countries $(7.6 \%)$ was lower $(2.3 \%)$ than in Ukraine.
The unemployment rate of young people aged 15-24 is almost double the average for the general population. Material problems, psychological discomfort due to lack of work force young people to engage in activities that are often dangerous to society. From the above, it follows that unemployment not only leads to political, economic and social instability in the country, it also leads to a significant burden on working people against the background of the demographic crisis, creating additional new risks. The return of Ukrainian migrants from abroad as a result of the spread of coronavirus and the loss of job further deepens the problem of unemployment and moneylessness in Ukraine, leading to new risks in other spheres of public life. The consequences of the risk of unemployment are low wages, which reduce solvent demand and reduce GDP growth, as well as increase budget spending on social security. In general, unemployment leads to the poverty of the population, the washing out of social values, the spread of corruption and criminalization and etc.

The depreciation of labour is a serious threat that affects the worsening employment situation. The wages of most workers do not fulfil incentive, motivational and reproductive functions. Unfortunately, in Ukraine in 2016 the share of wages in the total income of the population as a whole in the country amounted to $46.7 \%$, and in certain regions barely reached the 30\% mark (Yatsenko, 2016). The relationship between factors and manifestations of social risks on the quality of life of the population is shown in figure 1.

The average wage of full-time employees in 2017 was 7104 UAH, $90 \%$ of full-time employees who have worked $50 \%$ or more of the established monthly working hours, received a salary not exceeding 3,200 UAH, and another $24,4 \%$ of employees were paid wages in the amount of up to 4,000 UAH or almost at the level of actual amount of marginal profit taking into account the amount of tax on personal income (UAH 3924) (Yatsenko, 2016). Consequently, the wages of one third of workers are only able to provide a simple reproduction of the labour force today. In general, it should be noted that the impact of pay as a factor of social risks in the context of sustainable development, covers the whole system of risks of human development. Owing to excessive and unreasonable differentiation of salary of separate categories of workers the social tension grows in society and adding its low level in the majority of segments of the population it also deepens social inequality, leads to social instability. Among the negative effects of low wages should also include unfavourable and traumatic working conditions for people of working age, especially men, resulting in deteriorating health, high mortality 


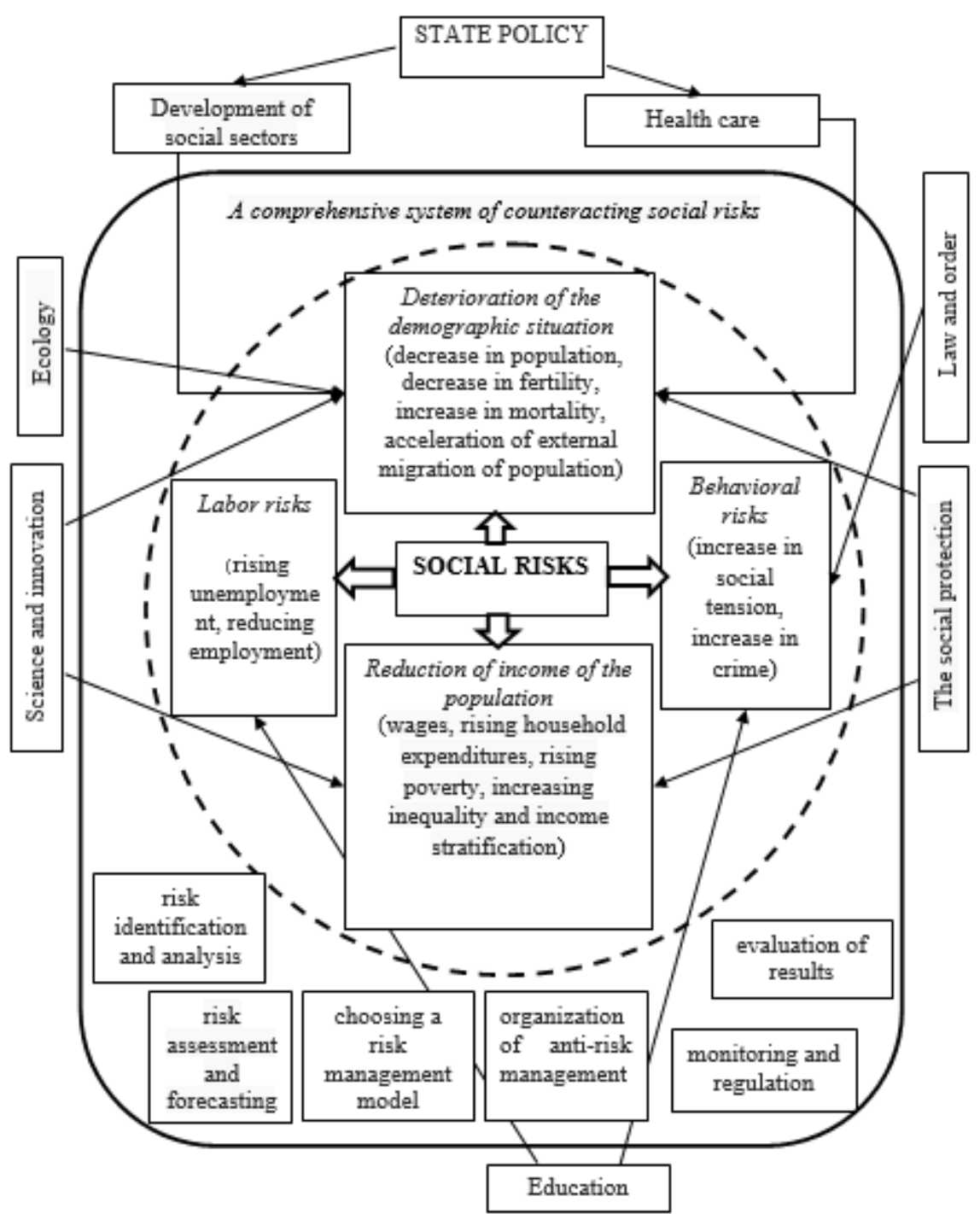

Figure 1. Model of counteraction to social risks in the spheres of human life in the conditions of sustainable development of Ukraine, source: author's development

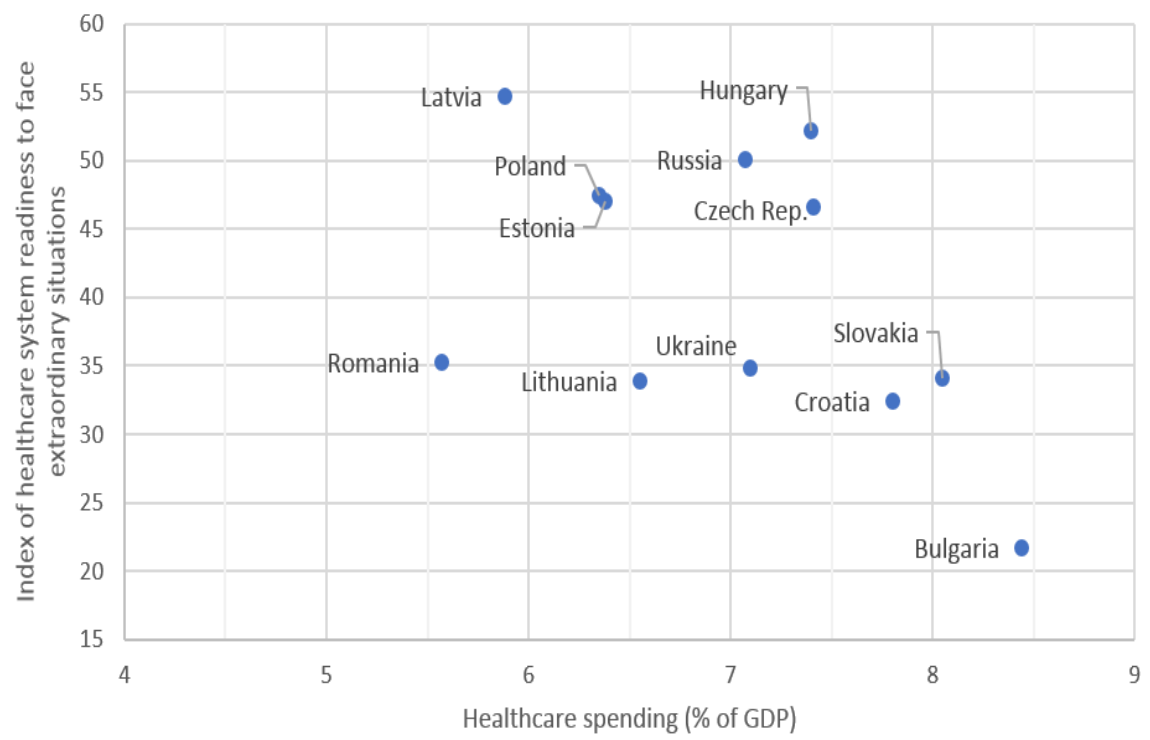

Figure 2. Index of Healthcare System Readiness to face the consequences of the coronavirus pandemic in Eastern Europe, source: author's development 
and social insecurity for those who have lost their health.

The total COVID-19 epidemic has become a challenge for humanity, where there is an aggressive manifestation of social risks in the healthcare sector. In Western European countries, as a result of the start of vaccination of the population at the end of 2020 , the incidence trend, which manifested itself in 2019, is gradually normalizing. In the group of Eastern European countries, the manifestation of social risks became more pronounced in late spring-autumn 2020. Figure 2 shows the Index of Healthcare System Readiness to face the consequences of the coronavirus pandemic in Eastern Europe (as of March 2021). At the beginning of 2021, mortality from the disease amounted to about $1.2 \%$ of the total number of cases, with $88 \%$ of all deaths occurring in people aged 65 and over (COVID-19 and Human Development: Assessing the Crisis, Envisioning the Recovery, 2020). And Ukraine as of 14.04.2021 is the leader in terms of mortality and ranks 3rd in terms of COVID-19 infection among the countries of Eastern Europe.

At the same time, mutations of the virus were noted in 2021 and more infections are observed in the younger generation, which is extremely dangerous. The consequences of the pandemic for the political, economic and social development of the world can already be predicted today. The pandemic crisis has negatively affected almost all sectors of the world economy. Over the next 5-10 years, a significant decline is expected in all sectors of production and agriculture. After growing by $2.5 \%$ in 2019 , global GDP in 2020 decreased by $2 \%$, and in the first half of 2021 - this decline will continue. The recession is also expected in the markets of 68 countries, compared to 11 countries last year, a decrease in international trade by $4.3 \%$ and an increase in world bankruptcies by $25 \%$. Due to this, there is already a rapid rise in unemployment in the small and medium business sector. According to analysts, it could reach $15 \%$ growth in the world and $20 \%$ in Europe. These phenomena can cause significant social unrest, as retraining people and creating huge numbers of jobs in new sectors of the economy will be much slower than the destructive processes of the previous economic system (COVID-19 and Human Development: Assessing the Crisis, Envisioning the Recovery, 2020).

The UN in its Future Possibilities Report, 2020 identified six megatrends that transform the world after the end of the COVID-19 pandemic. They are as follows (Future Possibilities Report, 2020):

1. The Big Data Economy;

2. The Wellbeing Economy;

3. Low-Carbon Economy;

4. The Circular Economy;

5. The BioGrowth Economy;
6. The Experience Economy.

Thus, the analysis of the development of the COVID-19 pandemic at the beginning in the world showed that the developed countries of Western Europe, which were connected by the largest number of business, trade and transport contacts, both with China and among themselves, then the United States, suffered the most. A certain time lag in the spread of the pandemic allowed European countries to introduce quarantine measures and prepare for the response to the disease. It should be noted that in the countries of the post-Soviet camp (Ukraine, Belarus, etc.), in contrast to Western European countries, the manifestation of social risks is more aggressive, which is associated with poor government management and uncertainty about the start of vaccination of its own population (Ukraine). While almost all European countries have started vaccinations, Ukrainian citizens are left behind in this indicator. At the beginning of April 2021 Ukraine ranked 50th in terms of vaccination among 58 European countries. Therefore, the problem of social risk management, especially in the field of health care, is extremely important at the state level. For Ukraine, it is of particular importance, which is associated with the poverty of the population, rising unemployment and insecurity from the health care system and the state.

The intensification of innovative processes of sustainable development Ukraine makes it necessary to focus on increasing the role of education and vocational training in the development of human resources. Especially this problem was actualized in the conditions of the economic development, where knowledge becomes a key factor. Increasing the level of labour quality requirements with the development of modern technologies requires constant improvement of the knowledge and skills of the individual during his/her working life in order to ensure his/her employment, professional mobility and competitiveness in education and employment. A new way of communication creates a new outlook on society. Smart work, work at home, and distance learning are becoming the business card of the present for Ukraine. In the conditions of formation of an innovative society the functional features of education are not only the ability to provide students with knowledge and skills gained in previous years, but also to increase the ability to perceive and use new scientific ideas, technical tools and production methods in practice, to develop innovative skills, initiative and entrepreneurship in workers (Popadynets et. al., 2020). Among the factors that characterize the quality of the labour force is not only the level of its vocational training but also the ability to perceive innovations, psychological stability, the acquisition of new knowledge and skills, the presence of stable motivational attitudes to improve professional standards throughout life. 
The effects of social risks in Ukraine increase risks of a non-social nature. The latter include adverse socioeconomic and political changes; instability of the current legislation; Limited or incomplete information on the dynamics of macroeconomic changes, Shadowing of the economy; Fluctuations in market conditions in the world market etc.

You can reduce the negative impact of risks in various spheres of public life in conditions of sustainable development by learning to manage them.

Social risk management requires an comprehensive approach to prevention, minimization of negative social consequences, and special attention should be paid to the analytical stage of social risk management to determine the factors and prerequisites for the formation of social risks. A comprehensive social risk management system can include (1) risk identification and analysis; 2) assessment and prediction of the risk situation; 3 ) selection of risk management model; 4) organization of anti-risk management; 5) monitoring and regulation; 6) assessment of results.

\section{Conclusions}

A feature of the manifestation of social risks in the conditions of sustainable development of Ukraine is that they are diverse: the manifestation in one sphere of human life leads to the consequence or enhances their action in another sphere of life.

It has been established that demographic risks are increasingly evident against the background of population ageing, depopulation and reduction of life expectancy. Forced labour migration of the population has an even greater impact on the state of demosituation.

Employment risks show that there is a continuing imbalance between supply and demand, the depreciation of labour and the loss of its motivational values. The most dangerous age category is young people and older people of working age. Not the possibility of self-realization in the sphere of work leads to an increase in crime, premature death, morbidity of socially dangerous diseases. The wages of one third of workers can provide only simple reproduction of the labour force. The impact of pay as a factor of social risks covers the whole system of risks of human development. Due to excessive and unjustified differentiation of wages of certain categories of workers, social tensions in society increase, and adding its low level in the majority of the working-age population it also deepens social inequality, leads to social instability.

Among the factors that characterize the quality of the labour force is not only the level of its vocational training, but also the ability to perceive innovations, learn new knowledge, and the existence of stable motivational attitudes to improve professional standards throughout life. Education as a factor of stabilization of tension in society in the context of sustainable development, can smooth and prevent risks in the sphere of labor.

Therefore, at the stage of Ukraine 's transition to a knowledge society, the role of lifelong education has a particular importance and needs close attention from the state and needs close attention from the state.

So, as the analysis of certain components of the social sphere has shown, in the conditions of sustainable development of Ukraine has formed prerequisites for increasing the probability of the onset and realization of various types of social risks both for the state and for each of its citizens. They were exacerbated by the global crown virus pandemic. It should also be emphasized that the system of social risks is not permanent, it changes in accordance with the directions of development of the state, so Ukraine is updating the problem of creating an effective system of measures aimed at preventing risks, reducing the probability of their occurrence and preventing the negative consequences of their occurrence.

Further study of risks in the social sphere will be aimed at exploring their manifestations in the educational sphere and human behavior.

\section{References}

1. ANDRUSIV U., GALTSOVA O, 2017, Evaluation of innovation activity of construction enterprises, $\mathrm{Sci}$ entific bulletin of Polissia, 3(11): 204-215.

2. CHELA B., 2017, Human Development Index: Ukraine is falling for what to do, http: www.ua.undp.org/content/ukraine/uk/home/ourperespective/ourperspectivearticles/2017/04/13/-.html (25. 07.2020).

3. CLOUGHERTY J.E., SOUZA K., CULLEN, M.R., 2010, Work and its role in shaping the social gradient in health, Ann N Y Acad Sci, 1186: 102-24.

4. CORONAVIRUS: STATISTICS BY COUNTRY, 2021, https://index.minfin.com.ua/ua/reference/coronavirus/geography/ (14.04.2021).

5. COVID-19 AND HUMAN DEVELOPMENT: ASSESSING THE CRISIS, ENVISIONING THE RECOVERY, 2020, http://hdr.undp.org/en/hdp-covid (12.04.2021).

6. DELANEY J.M. and DEVEREUX, P.J. 2019, More education, less volatility? The effect of education on earnings volatility over the life cycle, Journal of Labor Economics, 37(1): 101-137.

7. DELANEY J.M., 2019, Risk-adjusted returns to education, Education Economics, 27(5): 472-487.

8. FALCONI A.M., WEBER A.M., CULLEN M.R., STEFANICK M.L., MICHAEL Y.L., DARMSTADT G.L., 2020, Shifts in Women's Paid Employment Participation During the World War II Era and Later Life Health, Journal of Adolescent Health, 66(1): S42-S50.

9. FUTURE POSSIBILITIES REPORT, 2020, United Nations Organization, https://www.un.org/sites/ un2.un.org/files/20200720_un75_uae_futurepossibilities report.pdf (12.04.2021). 
10. IEVDOKYMOV V., LEHENCHUK S., ZAKHAROV D., ANDRUSIV U., USATENKO O., KOVALENKO L., 2020, Social capital measurement based on 'The value explorer' method, Management Science Letters, 10(6): 1161-1168.

11. KARIMI F., TOIKKA A., HUKKINEN J.I., 2016, Comparative socio-cultural analysis of risk perception of Carbon Capture and Storage in the European Union, Energy Research and Social Science, 21: 114122.

12. KINASH I. P., ARKHYPOVA L. M., POLYANSKA A. S., DZOBA O. G., ANDRUSIV U. Y.. IURAS I. I., 2019, Economic evaluation of tourism infrastructure development in Ukraine, ipaper presented at the IOP Conference Series: Materials Science and Engineering, 477(1).

13. KNEYSLER O., ANDRUSIV U., SPASIV N., MARYNCHAK L. KRYVYTSKA O., 2020, Construction of economic models of ensuring Ukraine's energy resources economy, paper presented at the 2020 10th International Conference on Advanced Computer Information Technologies, ACIT 2020 Proceedings: 651-656.

14. LE COZE J., 2018, An essay: Societal safety and the global 1, 2, 3, Safety Science, 110: 23-30.

15. MALINOVSKAYA O., 2016, Migration in Ukraine: facts and figures, IOM Representations in Ukraine.

16. MOTTA R., 2015, Transnational Discursive Opportunities and Social Movement Risk Frames Opposing GMOs, Social Movement Studies, 14(5): 576-595.

17. MOZGOVAYA A.V., 2018, Social sphere: Vectors of change, risks, and adaptation resources: The results of all-Russian monitoring surveys, RUDN Journal of Sociology, 18(4): 708-718.

18. POPADYNETS I., ANDRUSIV U., SHTOHRYN M., GALTSOVA O., 2020, The effect of cooperation between universities and stakeholders: Evidence from Ukraine, International Journal of Data and Network Science, 4(2): 199-212.

19. PROBLEMS AND PROSPECTS OF INNOVATIVE ECONOMIC DEVELOPMENT IN THE CONTEXT OF UKRAINE'S INTEGRATION INTO THE EUROPEAN SCIENTIFIC AND INNOVATION SPACE, 2017, Proceedings of the XXII International Scientific and Practical Conference, Odessa, Ukraine.

20. RUESGA-BENITO S.M., GONZÁLEZ-LAXE F., PICATOSTE X., 2018, Sustainable development, poverty, and risk of exclusion for young people in the European Union: The case of NEETs, in: Sustainability (Switzerland), 10(12).

21. SCHURING M., SCHRAM J.L.D., ROBROEK S.J.W., BURDORF A., 2019, The contribution of health to educational inequalities in exit from paid employment in five European regions, Scandinavian Journal of Work, Environment and Health, 45(4): 346-355.

22. SHAPOVALOVA I.S., POLUKHIN O.N., GERASHCHENKO V.M., KISILENKO A.V., GOZHENKO G.I., 2018, Social and cultural threats and risks of Russia, Journal of Social Sciences Research, Special Issue 5: 235-240.

23. SHAPOVALOVA I.S., ZAKHAROV V.M., SHMIGIRILOVA L.N., KISISLENKO A.V., GOZHENKO G.I., 2016, Social risks of human habitat, Social Sciences (Pakistan), 11(10): 2416-2420.
24. STATE STATISTICS SERVICE OF UKRAINE, 2018, Economic Activity of the Population of Ukraine, $205 \mathrm{p}$.

25. STATE STATISTICS SERVICE OF UKRAINE, 2019, Report of the Survey of Innovation Activity in the Economy of Ukraine (by the International Methodology) in 2014-2016, http://www.ukrstat. gov.ua/ (23.07.2020).

26. STATE STATISTICS SERVICE OF UKRAINE, 2020, The population of Ukraine, http://www.ukrstat.gov.ua/operativ/operativ2007/ds/nas_rik/nas_u/ nas_rik_u.html (23.07.2020).

27. TKACHENKO L., 2017, The Three Horsemen of the Demographic Apocalypse. Key Trends in Ukraine, Mirror of the Week.

28. WORLD HEALTH ORGANIZATION, 2015, Life expectancy Data by country.

29. YATSENKO L., 2016, Tensions in the Ukrainian labor market: factors, social consequences and ways to overcome them, Social Policy Series, 29.

30. ZELINSKA H., ANDRUSIV U., SIMKIV L., 2020, Knowledge economy: trends in the world and analysis of Ukraine, Journal of Eastern European and Central Asian Research, 7(1): 104-113.

31. ZELVIENE, P., KAZLAUSKAS, E. and MAERCKER A., 2020, Risk factors of ICD-11 adjustment disorder in the Lithuanian general population exposed to life stressors, European Journal of Psychotraumatology, 11(1). 